\title{
COMPARATIVE STUDY OF THE SIGNIFICANCE OF COMPETITION INDICES AND GENOTYPE OF SCOTS PINE TREE REACTIONS TO CHANGES IN METEOROLOGY AND AIR POLLUTION
}

\begin{abstract}
Marius MIKALAJŪNAS, Institute of Forestry, Faculty of Forest and Ecology, Aleksandras Stulginskis University, Studentu str. 11227, Akademija, LT-53361, Kaunas distr, Lithuania; marius.mikalajunas1990@gmail.com (corresponding author)

Giedrius ŠIDLAUSKAS, Institute of Forestry, Faculty of Forest and Ecology, Aleksandras Stulginskis University, Studentu str. 11227, Akademija, LT-53361, Kaunas distr, Lithuania; giedrius.asu@ gmail.com

Edgaras LINKEVIČIUS, Institute of Forest Management and Wood Science, Faculty of Forest Sciences and Ecology, Aleksandras Stulginskis University, Studentų 13, Lithuania; edgaraslinkevicius@ yahoo.com

Darius KAVALIAUSKAS, Institute of Forest Biology and Silviculture, Aleksandras Stulginskis University, Studentu str. 11-227, Akademija, LT-53361, Kaunas distr, Lithuania

Changing climatic conditions, increased length of growing season, competition, genotype and pollution are the most important factors for tree productivity and health. That is why only by knowing the impact of these factors on trees we can evaluate and change sylvicultural treatments that are important for the health and productivity of forest in Lithuania. The aim of the present study was to detect the significance of the competition index vs. genotype of Scots pine trees on their reactions to changes in meteorology and air pollution. Tree health, dendrometric parameters and stem basal area increment were chosen as response variables to meet the objectives of the presented study. The investigation was carried out at Scots pine genetic stand located in Aukstaitija national park, Vaisniunai district. Data on meteorology and air pollutants were obtained from ICP Integrated Monitoring Station located there. Genetically related individual groups in the stand were established by the neutral part of the genome of short repeated DNA sequence length polymorphism markers. Trees of distinctive short repeated sequences allele frequencies were grouped by Bayesian cluster analysis methods. Four genetically similar tree groups were separated in the monitored stand based on significance of $\Delta \mathrm{K}$ value. Seven competition indices were used to determine the competition intensity effect on the tree increment and their dendrometric parameters including crown condition. The obtained results revealed that trees which demonstrated the most intensive BAI formation, best crown condition and the most significant reaction to changes in meteorology and air pollution comprised one tree genetic group while trees with adverse characteristics the second. Notwithstanding this competition intensity had the most significant effect on BAI formation.
\end{abstract}

Keywords: Scots pine, dendrometric parameters, radial increment, crown defoliation, competition index, genetic group, air pollution.

\section{INTRODUCTION}

Changes in average climatic conditions such as air temperature, precipitation amount and the length of growing season that influence site productivity (Fabian and Menzel 1999) could result in changes in tree species and their capacity to adapt and mitigate the new threats resulted by global changes (Sicard at al., 2016). Then claiming that trees are most important part of ecosystem we can expect difficulties for forests as entirety. Considering that 'community and ecosystem phenotypes' have a genetic basis and are heritable, we can begin to apply the principles of population and quantitative genetics to place the study of complex communities and ecosystems within an evolutionary framework (Whitham et al., 2006). This framework could allow us to understand, the genetic basis of ecosystem processes, and the effect of such phenomena as climate change so that a genotype which is more adaptive for local environmental condition could be chosen. Association between commercial value and genetic diversity is weak in Scots pine. Scots pine thinning causes inbreeding and loss of rare alleles but, for specific cases, it could be possible to slower rate of rare allele loss by choosing right thinning intensity and removing the spike knot or tree forking defect trees with phenotypic trait indicating lowheterozygosity trees in the young stand. (Danusevicius 2016). By studying such genetic interactions of foundation species and their dependent community members through time, we can critically address how gene-environment interactions affect community structure, ecosystem processes such as nutrient cycling, and evolution in the context of both communities and ecosystems. (Whitham et al., 2006). Such studies require long-term climate monitoring, observe phenology of plants, compare and analysis (Kim et al., 2012).

On the other hand one of the most important factors of tree productivity and their increment in a stand is competition intensity among tree individuals. Competition can be evaluated as individual tree accessibility to nutrition

Copyright (C) 2017 The Authors. Published by Aleksandras Stulginskis University. This is an open-access article distributed under the terms of the Creative Commons Attribution License (CC-BY 4.0), which permits unrestricted use, distribution, and reproduction in any medium, provided the original author and source are credited. 
and light resources. This competition is explained by competition indices and depends on tree species, diameter, height, crown size and distance between competitors (Pretzsch, 2009). It is a key parameter which results in tree condition in general. Competition has a purely negative impact on tree diameter growth. Increasing competition leads to steady decreases in diameter increment. Nevertheless, although a small amount of competition does stimulate tree height growth, stronger competition has a lasting negative impact on tree height growth (Linkevičius 2014).

To evaluate the integrated effect of environmental factors including meteorology and acidifying pollutants, tree ring formation as a response variable was used. Conifers are one of the most sensitive forest tree species (Augustaitis et al., 2007a, 2007b, 2010a, 2010b, Augustaitis, 2011, Juknys at al., 2014, Ozolincius and Stakenas, 2001, Ozolincius et al., 2005). Scots pine (Pinus sylvestris L) has a large area habitat, which stretches across Europe and Asia. Pine is the most abundant tree species in Lithuania, which occupies about 713159 ha $(2017 \mathrm{~m}$.) what makes $37.6 \%$ of the total forest area (Lithuanian forest inventory, 2017). Its productivity and health are under the greatest concern in Lithuania. Therefore, this tree species was selected as the main research object to meet the aim of the study.

The aim of this study was to detect the significance of competition index vs. genetic diversity of Scots pine trees and their reaction to changes in meteorology and air pollution. To meet this aim we attempted to detect:

- the effect of competition intensity on pine tree parameters, crown health and stem annual increment;

- the significance of differences among tree characteristics representing different tree genetic groups;

- the effect of meteorology and air pollutants on tree ring formation in relation to tree genotype;

- the significance of Scots pine tree competition indices vs. their genotype and their reactions to changes in meteorology and air pollution.

\section{MATERIAL AND METHODS}

Aukstaitija NP Vaisniunai forest enterprise Scots pine (Pinus sylvestris) genetic stand which is located in the eastern part of Lithuania and belongs to south eastern Lithuanian highland region was chosen to meet the main objectives of the study. Altitude of the stand made $170 \mathrm{~m}$ above sea level. In this stand 1 ha permanent observation site was established. Tree position in the selected plot, all their dendrometric parameters and crown health were monitored annually since 2012 . Main dendrometric parameters were as follows: tree diameter $\mathrm{D}_{1,3}(\mathrm{~mm})$, height $\mathrm{H}-(\mathrm{dm})$, crown height $(\mathrm{Cr} \mathrm{h}, \mathrm{dm})$, length $(\mathrm{Cr} 1, \mathrm{dm})$ and diameter $(\mathrm{Cr} \mathrm{dm}, \mathrm{dm})$, and area $\left(\mathrm{Cr}\right.$ area $\left.\mathrm{m}^{2}\right)$ as well as crown defoliation $(\%)$.

Genetically similar groups of individuals were determined by neutral genome DNR short repeated sequences length polymorphism markers. They reflect genetic family ties and evolutionary origin differences (White et. al. 2007). This method was chosen because functional genome part in one adaptive environment is unlikely to be different. Four short repeated sequences allele frequencies (genetic composition) having individual genetic groups (GG) were extracted by using Bayesian cluster analysis method, which is one of the most reliable nonparametric methods among other statistical grouping methods (Danusevicius et al, 2016).

Meteorological parameters for the two last and a current seasons collected from September through August were used to identify the key factors driving to the variation in tree growth intensity on the chosen FS. Pearson's correlation analysis was used to examine the relationship between stem BAI and meteorology. Significance of each predict variable was detected by using the level of significance $\mathrm{p}<0.05$.

The effects of environmental factors on tree-ring width data sets were studied by response function analysis (Kairiukstis et al., 1987; Augustaitis and Bytnerowicz, 2008; Juknys et al., 2003, 2014). The width of annual tree-rings in stem cores was measured to the closest $0.01 \mathrm{~mm}$ using an electronic transducer and a binocular scope fixed over the moving stage of "Lintab6" equipment. The individual tree-ring width series were synchronized by visual comparison of ring width graphs (Eckstein, 1989) and statistically by calculating the Pearson's coefficients of correlation among them (Baillie \& Pilcher 1973). The mean tree-ring width data series for each genetic group were calculated based on measured bores of all trees, where DNR analysis was performed (approximately 100 trees for each group). Program packet TSAP (TSAP by FRANK RINN and SIEGWARD JAKEL, Heidelberg, Germany) was used for yearly radial increment dating and tree radial increment synchronizing. To eliminate the effect of age on tree-ring width (Holmes 1994), the stem basal area increment (BAI) was computed. BAI chronology was computed by averaging the BAI for each year across all trees sampled on that site as responding growth factor.

Seven competition indices (CI) based on a distance between sampled trees and an adverse cone angle were used to detect the most significant competition index explaining the variation in dendrometric parameters, crown condition and stem increment (Linkevičius, 2014). When setting the search cone, two important features were taken into account. The first was the location of where the bottom of the inverse cone is set and the second was the opening angle of the search cone. This study focuses on three separate positions to set the inverse cone: i) at the height of the crown base, ii) at the height of widest crown width, iii) at the stem base. The opening angle of the search cone was 60,70 or 80 degrees. Trees that fell inside the search cone area were identified as competitors. In the context of estimating the strength of competition seven distance dependent CIs proposed by Hegyi (1974), Biging \& Dobbertin (1992), Pretzsch (1995), and Schroder (2004) were taken into account. The indices developed by Wykoff et al. (1982) CI_BAL and Hegyi (1974) CI_HEGY are based on the relative sizes of tree diameters at breast height in comparison with larger and nearest competitors tree diameters respectively. Hegyi (1974) CI_HEGY 2 is based on tree basal area ratio in comparison with the basal area of the nearest competitor tree. The CIs developed by Pretzsch (1995) CI_Pretz, Schroder (2004) $C I \_V K F$ and the two developed by Biging and Dobbertin (1992) CI_BDKV and CI_BDKF were based on the relative crown sizes such as tree horizontal crown area $\left(\mathrm{h}_{\mathrm{ca}}, \mathrm{m}^{2}\right)$, vertical crown area $\left(\mathrm{V}_{\mathrm{ca}}, \mathrm{m}^{2}\right)$ and crown volume $\left(\mathrm{CV}, \mathrm{m}^{2}\right)$. One of the considered $\mathrm{CI}$ was selected to detect the significance of competition intensity to tree reaction to environmental changes. 


\section{RESULTS AND DISCUSSION}

Effect of competition intensity on tree dendrometric characteristics, stem increment and crown condition

The state of knowledge revealed that competition intensity has a consistent negative impact on tree ring width formation; when the increase in competition results decrease in the tree ring width formation. By contrast, lower competition stimulates tree height growth, but stronger competition also has a negative impact on tree increment in toll (Pretzsch, 2009; Linkevičius et al., 2011, 2014). The obtained data confirmed this state of knowledge. All selected competition indices demonstrated direct effect on pine stem radial increment. CI Pretcz and CI Hegyl 2 demonstrated the most significant effect on stem diameter at breast height using adverse cone located at stem base. They explained up to $30 \%$ variation in stem diameter variation of pine trees. Finally, CI Pretcz based on horizontal crown area and distance to the nearest competitor tree was selected to detect significance of competition intensity vs. tree genome on tree reaction to different environmental condition.

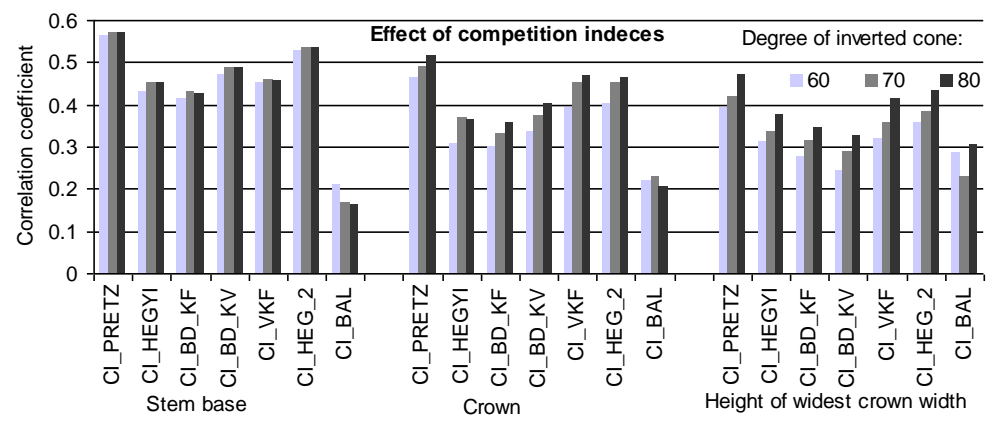

Figure 1. Effect of the detected competition indices based on the location of where the bottom of the inverse cone is set and the angle of the used cone $\left(60^{\circ}, 70^{\circ}, 80^{\circ}\right)$ on pine tree $\mathrm{DBH}$ variation

\section{Dendrometry, crown condition and tree ring width of pine trees representing different genetic groups}

Effect of tree genome was detected by applying ANOVA t test of variation in dendrometric parameters, crown condition and stem increment rate of trees representing 4 different GGs. After the elimination of trees, probability to represent the GG of which was lower than $60 \%$, significant differences among tree height and crown defoliation were established (Table 2). A difference among mean tree diameters from these groups was close to the level of significance. Competition intensity between trees representing these GGs was also statistically significant.

Table 1. Mean characteristics of pine trees representing different genetic groups and their significance (ANOVA test)

\begin{tabular}{|c|c|c|c|c|c|c|c|c|c|}
\hline \multirow{2}{*}{ Parameter } & \multicolumn{2}{|c|}{ GG - 1 } & \multicolumn{2}{c|}{ GG - } & \multicolumn{2}{c|}{ GG - 3 } & \multicolumn{2}{c|}{ GG - 4 } & Statistic \\
\cline { 2 - 11 } & Numbe & Mean & Numbe & Mean & Numbe & Mean & Numbe & Mean & P value \\
\hline Tree DBH, cm & 64 & 22.2 & 78 & 22.9 & 106 & 23.6 & 95 & 21.6 & 0.069 \\
\hline Tree height, m & 64 & 21.6 & 78 & 21.8 & 106 & 22.2 & 95 & 21.1 & $\mathbf{0 . 0 1 2}$ \\
\hline Crown height, m & 64 & 13.1 & 78 & 13.3 & 106 & 13.6 & 95 & 13.1 & 0.304 \\
\hline Crown area, m ${ }^{2}$ & 64 & 17.2 & 78 & 17.4 & 106 & 18.0 & 95 & 17.4 & 0.226 \\
\hline Defoliation, \% & 64 & 18 & 78 & 16.5 & 106 & 15.0 & 95 & 22.9 & $\mathbf{0 . 0 0 7}$ \\
\hline CI PRETZ SB 80 & 64 & 17.4 & 78 & 15.2 & 106 & 12.8 & 95 & 33.1 & $\mathbf{0 . 0 0 8}$ \\
\hline $\operatorname{Zr}(2010-2014)$, & 63 & 0.805 & 76 & 0.904 & 105 & 1.003 & 93 & 0.765 & $\mathbf{0 . 0 1 1}$ \\
\hline $\operatorname{Zr}(2005-2009)$, & 63 & 1.229 & 76 & 1.371 & 105 & 1.437 & 93 & 1.210 & $\mathbf{0 . 0 2 9}$ \\
\hline $\operatorname{Zr}(2000-2004)$, & 63 & 1.643 & 76 & 1.772 & 105 & 1.873 & 93 & 1.527 & $\mathbf{0 . 0 0 9}$ \\
\hline
\end{tabular}

A rather significant difference was established when analyzing the annual either radial or basal area increment of pine trees (Fig. 2). Since 2000 these differences have also been found statistically significant $(\mathrm{p}<0.05)$.
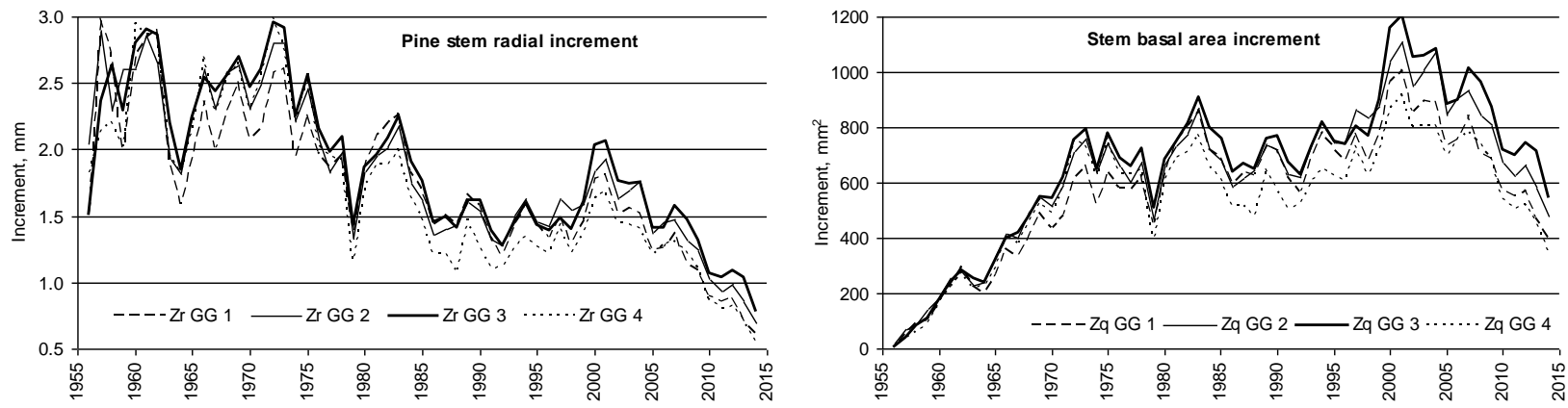

Figure 2. Data series on stem radial and basal area increments of pine trees representing four genetic groups of middle-aged stands: 
Having generalized the obtained data we could conclude that trees which demonstrated the best dendrometric parameters, healthiest crown condition and highest increment rate represented a separate GG-3, while trees with adverse characteristics - GG-4.

\section{Effect of meteorology on annual tree ring formation of pine trees representing different genetic groups}

In temperate climate zone tree stem radial increment is mainly influenced by the temperature of last year autumn (September, October) and winter, and temperature of the early spring (February, March, April) of the current year as well as temperature of late summer (August). Quite often this effect is reinforced by winter and summer precipitation (Mäkinen et al., 2001; Tardif et al., 2001). The results our studies in general confirmed these findings.

The obtained data revealed that warmer dormant period from December through April had a statistically significant effect on the increase in stem BAI formation of pine trees representing all GG (Fig. 3). The effect of warmer July and August reinforced this positive effect of warmer dormant period, however this process was only close to the level of significance $(\mathrm{p}<0.1)$. Only the heat in June inhibited growth intensity of pine trees, however this detected relationship was also only close to the level of significance. In general, the established relationships well, reflected data obtained by A. Augustaitis et al., in 2007, 2015, 2018, which also indicated similar regularities in the effect of air temperature on pine BAI formation in mature and over mature pine stands in north eastern part of Lithuania. More significant positive and least significant negative effects of mean temperature of the considered months were detected on tree growth intensity from GG No 3. By contrast, the least significant positive and highest significant negative effect of the mean temperature of the considered months was established on trees from GG No 4. These tendencies in the level of significance of relationships between air temperature and stem BAI formation were the same for trees representing GG No 1 and No 2 respectively to their dendrometry and crown health.
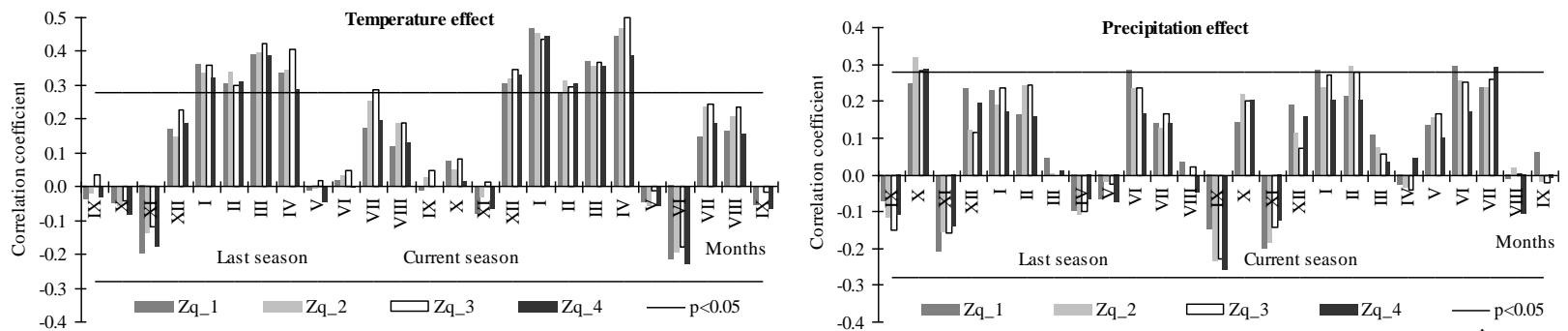

Figure 3. Effect of mean temperature and precipitation amount on stem basal area increment of pine trees representing four different genetic groups

Having generalized the obtained results, we could state that mean temperature of April of two seasons and June and August of the current season were mainly responsible for the dendrometric differences and growth rate intensity among trees representing different genetic groups in the middle-aged pine stands of Aukstaitija region in Lithuania.

Table 2. Multiregression models of stem BAI formation of pine trees representing 4 different genetic groups in relation to monthly mean temperature and precipitation amount of two growing seasons.

\begin{tabular}{|c|c|c|c|c|c|c|c|c|c|}
\hline \multicolumn{5}{|c|}{$\begin{array}{l}\text { Dependent Variable: } Z q_{-} 3 \text { (pine trees with biggest dendrometric } \\
\text { parameters and increment, and lowest defoliation rate) } \\
\mathrm{R}=0.821 ; \mathrm{R}^{2}=0.675 ; \text { Adj. } \mathrm{R}^{2}=0.614 ; \mathrm{F}(8,43)=11.15 ; \\
\mathrm{p}<0.000 ; \text { Std.Error of estimate: } 128.32 \text { : }\end{array}$} & \multicolumn{5}{|c|}{$\begin{array}{l}\text { Dependent Variable: } Z \mathrm{Zq} \_4 \text { (pine trees with smallest dendrometric } \\
\text { parameters and increment, and highest defoliation rate) } \\
\mathrm{R}=0.767 ; \mathrm{R}^{2}=0.589 ; \text { Adj. } \mathrm{R}^{2}=0.512 ; \mathrm{F}(8,43)=7.71 ; \\
\mathrm{p}<0.000 ; \text { Std.Error of estimate: } 121.92 \text { : }\end{array}$} \\
\hline & B & Std.Err. & $\mathrm{t}(43)$ & p-level & & B & Std.Err. & $\mathrm{t}(43)$ & p-level \\
\hline Intercept & -120.092 & 321.041 & -0.374 & 0.71 & Intercept & 205.816 & 305.051 & 0.675 & 0.503 \\
\hline $\operatorname{Pr} X$ & 1.899 & 0.607 & 3.130 & 0.003 & $\operatorname{Pr} X$ & 1.674 & 0.577 & 2.904 & 0.006 \\
\hline $\operatorname{Pr} \mathrm{XI}$ & -1.991 & 0.802 & -2.484 & 0.017 & $\operatorname{Pr} \mathrm{XI}$ & -1.768 & 0.762 & -2.322 & 0.025 \\
\hline Pr II & 2.072 & 0.757 & 2.736 & 0.009 & Pr II & 1.109 & 0.72 & 1.541 & 0.131 \\
\hline Pr VI & 1.055 & 0.504 & 2.095 & 0.042 & Pr VI & 0.505 & 0.479 & 1.056 & 0.297 \\
\hline Pr VII & 2.289 & 0.531 & 4.311 & 0.000 & Pr VII & 1.944 & 0.505 & 3.852 & 0.000 \\
\hline Tm I & 21.334 & 4.487 & 4.754 & 0.000 & Tm I & 18.325 & 4.264 & 4.298 & 0.000 \\
\hline Tm VI & -28.969 & 12.029 & -2.408 & 0.020 & Tm VI & -26.873 & 11.43 & -2.351 & 0.023 \\
\hline Tm VIII & 62.196 & 14.279 & 4.356 & 0.000 & Tm VIII & 43.837 & 13.568 & 3.231 & 0.002 \\
\hline \multicolumn{5}{|c|}{$\begin{array}{l}\text { Dependent Variable: } Z \text { qq_2 (pine trees with a little smaller dendrometric } \\
\text { parameters than trees from genetic group 3) } \\
\mathrm{R}=0.806 ; \mathrm{R}^{2}=0.650 ; \mathrm{Adj} . \mathrm{R}^{2}=0.585 ; \mathrm{F}(8,43)=9.98 \\
\mathrm{p}<0.000 ; \text { Std.Error of estimate: } 124.43 \text { : }\end{array}$} & \multicolumn{5}{|c|}{$\begin{array}{l}\text { Dependent Variable: } \mathrm{Zq} \_1 \text { (pine trees with a little smaller dendrometric } \\
\text { parameters than trees from genetic group } 2 \text { ) } \\
\mathrm{R}=0.800 ; \mathrm{R}^{2}=0.640 ; \mathrm{Adj} . \mathrm{R}^{2}=0.573 ; \mathrm{F}(8,43)=9.54 ; \\
\mathrm{p}<0.000 ; \text { Std.Error of estimate: } 129.78 \text { : }\end{array}$} \\
\hline & & Std.Err. & $\mathrm{t}(43)$ & p-level & & $\mathrm{B}$ & Std.Err. & $\mathrm{t}(43)$ & p-level \\
\hline Intercept & -8.467 & 311.317 & -0.027 & 0.978 & Intercept & 214.998 & 324.697 & 0.662 & 0.511 \\
\hline $\operatorname{Pr} X$ & 2.027 & 0.588 & 3.444 & 0.001 & $\operatorname{Pr} \mathrm{X}$ & 1.571 & 0.614 & 2.560 & 0.014 \\
\hline $\operatorname{Pr} \mathrm{XI}$ & -1.904 & 0.777 & -2.45 & 0.018 & $\operatorname{Pr} \mathrm{XI}$ & -2.415 & 0.811 & -2.979 & 0.005 \\
\hline Pr II & 1.539 & 0.734 & 2.096 & 0.042 & Pr II & 1.572 & 0.766 & 2.052 & 0.046 \\
\hline Pr VI & 1.018 & 0.488 & 2.084 & 0.043 & Pr VI & 1.203 & 0.509 & 2.362 & 0.023 \\
\hline Pr VII & 1.96 & 0.515 & 3.806 & 0.000 & Pr VII & 1.85 & 0.537 & 3.445 & 0.001 \\
\hline Tm I & 20.749 & 4.351 & 4.768 & 0.000 & Tm I & 22.272 & 4.539 & 4.907 & 0.000 \\
\hline Tm VI & -25.705 & 11.665 & -2.204 & 0.033 & Tm VI & -31.185 & 12.166 & -2.563 & 0.014 \\
\hline Tm VIII & 53.237 & 13.847 & 3.845 & 0.000 & Tm VIII & 47.227 & 14.442 & 3.270 & 0.002 \\
\hline
\end{tabular}


The effect of precipitation amount on pine growth intensity was remarkably lower than that of temperature. Only in exceptional cases this relationship reached the level of statistical significance $(p<0.05)$. These obtained results also very well reflected the state of knowledge on pine growth peculiarities both in Lithuania (Augustaitis et al., 2015, 2018; Juknys et al., 2003, 2014) and Europe (Taeger et al. 2013). Notwithstanding this, more abundant precipitation during dormant period, i.e. from December through February, and during vegetation, i.e. from May through August of two seasons, resulted in more intensive growth rate of pine trees representing all GGs.

More abundant precipitation had a negative effect only in September and November, what was also typical not only for pine stem BAI formation in north-eastern part of Lithuania (Augustaitis et al., 2015, 2018) but also for changes in pine crown condition (Augustaitis et al., 2007, 2010a, 2010b; Augustaitis, 2011). However, precipitation of none of the months of two seasons significantly explained the differences in stem BAI of trees representing different GGs. The effect of precipitation in February was very close to this level. Notwithstanding this, the findings indicating that precipitation amount from May through July resulted in higher BAI were in full agreement with the presented results by another scientist (Taeger et al. 2013, Zang, 2012).

Meteorological multiple regression model was developed based on the monthly meteorological parameters, significance of which were higher or close to $\mathrm{p}<0.05$. Key meteorological parameters which composed the models were as follows: precipitation amount in October, November, February, June and July, and mean temperature in January, June and August. These predict variables best explained the growth intensity of pine trees from the most productive and healthiest GG-3, i.e. explanation rate exceeded 67\%. A little lower explanation rate demonstrated considered predict variables on the variation in BAI formation of trees from GG No 2 and GG No 1. Integrated effect of selected key meteorological factors explained up to 64-65\% variation in BAI formation respectively. Only 59\% explanation rate was established when analyzing the effect of the considered meteorological parameters on stem BAI of the least productive and worst condition pine trees representing GG No 4.

\section{Effect of air pollutants and acid deposition on stem BAI of trees representing different genetic groups}

Air concentrations of the acidifying compounds and their deposition mainly resulted in variation of Scots pine crown defoliation while their effect of tree ring formation is lower (Paoletti et al., 2007, Sicard et al., 2016) especially when their concentrations and loads do not exceed critical values (Holmberg et al., 2013; Vuorenmaa et al., 2017). The significant effect of these pollutants was established only in forest with few folds higher pollution load, which was detected in Lithuania at different distance from the nitrogen fertilizers plant "Achema" (Juknys et al, 2003, 2014). The obtained data revealed that acidifying compounds had a negative effect on stem BAI residuals (RES), when the effect of meteorology was accounted for, especially if the trees represented the best GG No 3 (Fig. 4). The effect of acidifying compounds on tree BAI RES from the other GGs represented significantly different results. In most cases positive, but not significant relationships between the considered variables were established. Exceptional case was the detected negative effect of ammonium deposition and positive effect of nitrate deposition on tree BAI RES from all GGs. These tree reactions to environmental pollution could be considered as key findings that tree genome has a significant effect on sensitivity of pine trees to air pollution of acidifying compounds and their deposition.

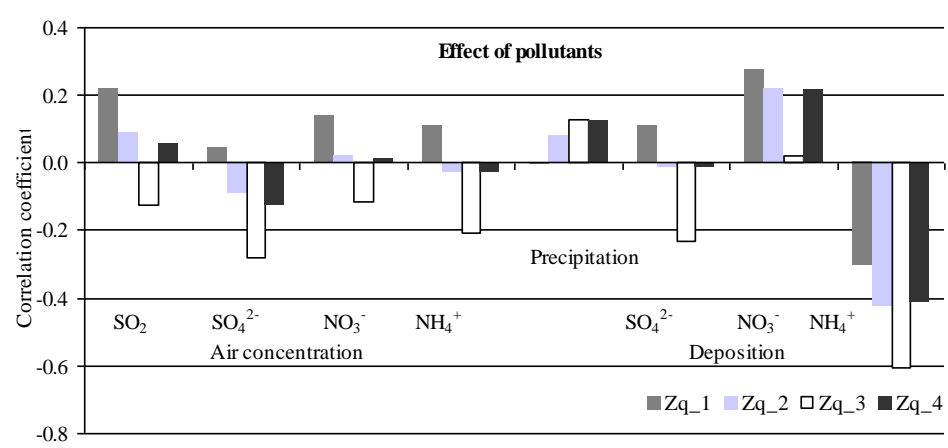

Figure 4. Relationship between the considered pollutants and stem basal increment of pine trees representing different genetic groups

The developed multi regression models revealed that $\mathrm{N}$ deposition alone had a significant effect on variation in stem BAI RES and if ammonium deposition load had a negative effect then nitrate deposition had a positive effect on variation in tree BAI RES (Table 3).

The obtained regularities were common for all trees representing all GGs. Difference arouse only in explanation rate of variation in BAI RES. The considered pollutants explained the variation in BAI RES of the best condition pine trees representing GG - 3 most significantly (more than 43\%). The effect of pollutants on tree BAI RES from the GG 2 was less significant and made $33 \%$, whereas the effect of acidifying compounds on pine tree BAI RES representing the worst GG -1 and GG 4 was the least and made approximately $25-27 \%$ and was not significant ( $>>0.05$ ). These results well agreed with state of knowledge in this field: the least adapted trees to environmental condition did not demonstrate significant reactions neither to favorable nor to unfavorable conditions. Following to this we could state that pines representing GG-4 were the least adapted to recent environmental condition and most probably they all will fall done with stand ageing process. 
Table 3. Integrated effect of $\mathrm{N}$ deposition on variation in stem BAI residuals of pine trees representing different genetic group.

\begin{tabular}{|c|c|c|c|c|c|c|c|c|c|}
\hline \multicolumn{5}{|c|}{$\begin{array}{l}\text { Regression Summary for Dependent Variable: Res. of GG-3 } \\
\mathrm{R}=0.655 \mathrm{R}^{2}=0.430 \mathrm{~F}(2,17)=6.40 \mathbf{p}<\mathbf{0 . 0 0 8} \text { Std.Err.Estm: } 102.3\end{array}$} & \multicolumn{5}{|c|}{$\begin{array}{l}\text { Regression Summary for Dependent Variable: Res. of GG-4 } \\
\mathrm{R}=0.520 \mathrm{R}^{2}=0.270 \mathrm{~F}(2,17)=3.14 \mathrm{p}<0.068 \text { Std.Err.Est.m: } 98.55\end{array}$} \\
\hline & $\mathrm{B}$ & Std.Err. & $\mathrm{t}(17)$ & p-level & & $\mathrm{B}$ & Std.Err. & $\mathrm{t}(17)$ & p-level \\
\hline Intercept & 29.35 & 171.213 & 0.171 & 0.866 & Intercept & -210.433 & 164.997 & -1.275 & 0.219 \\
\hline Dep $\mathrm{NO}_{3}^{-}$ & 1.241 & 0.91 & 1.363 & 0.191 & Dep $\mathrm{NO}_{3}{ }^{-}$ & 1.511 & 0.877 & 1.722 & 0.103 \\
\hline Dep $\mathrm{NH}_{4}{ }^{+}$ & -0.906 & 0.253 & -3.577 & 0.002 & Dep $\mathrm{NH}_{4}{ }^{+}$ & -0.564 & 0.244 & -2.310 & 0.034 \\
\hline \multicolumn{5}{|c|}{$\begin{array}{l}\text { Regression Summary for Dependent Variable: Res. of GG-2 } \\
\mathrm{R}=0.580 \mathrm{R}^{2}=0.336(2,17)=4.30 \mathbf{p}<\mathbf{0 . 0 3 0} \text { Std.Err.Estim.: } 109.4\end{array}$} & \multicolumn{5}{|c|}{$\begin{array}{l}\text { Regression Summary for Dependent Variable: Res. of GG-1 } \\
R=0.500 \mathrm{R}^{2}=0.250 \mathrm{~F}(2,17)=2.84 \mathrm{p}<0.085 \text { Std.Err.Estim.: } 105.9\end{array}$} \\
\hline & B & Std.Err. & $\mathrm{t}(17)$ & p-level & & B & Std.Err. & $\mathrm{t}(17)$ & p-level \\
\hline Intercept & -152.263 & 183.22 & -0.831 & 0.417 & Intercept & -290.099 & 177.353 & -1.636 & 0.120 \\
\hline $\mathrm{Dep} \mathrm{NO}_{3}^{-}$ & 1.936 & 0.974 & 1.988 & 0.063 & Dep $\mathrm{NO}_{3}{ }^{-}$ & 1.902 & 0.943 & 2.017 & 0.060 \\
\hline $\operatorname{Dep~} \mathrm{NH}_{4}{ }^{+}$ & -0.736 & 0.271 & -2.716 & 0.015 & $\operatorname{Dep~NH}_{4}{ }^{+}$ & -0.498 & 0.262 & -1.898 & 0.075 \\
\hline
\end{tabular}
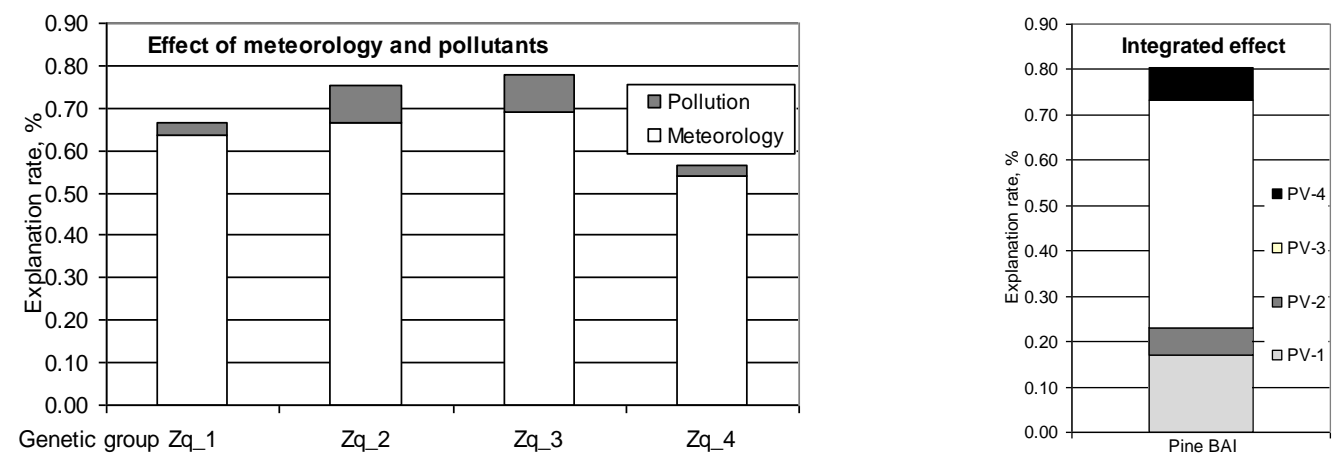

Note: PV-1 - competition intensity; PV-2 - genoptype; PV-3 - meteorology; PV-4 - N deposition.

Figure 5. Significance of theefect of pollutants and meteorology on stem BAI formation of pine trees representing different genetic groups (left) and the integrated effect of the considered predict variables (PV) on pine BAI formation (right) in north eastern part of Lithuania

Having generalized the obtained results we can conclude that meteorological parameters were the main drivers of stem growth intensity of pine trees representing four different GGs (Fig. 5). Effect of air pollutants and their deposition resulted in the stem BAI RES of the trees with biggest dendrometric parameters and healthiest crowns (GG-3) most significant. It allowed concluding that tree genotype has the significant effect on tree sensitivity to meteorology and acid deposition, but this effect is lower than the effect of tree competition intensity.

\section{CONCLUSION}

Competition index detected based on horizontal crown area and distance to nearest competitors tree best of all considered CI explained variation in tree stem diameter. After the elimination of trees, which probability to represent the GG was lower than 50\% significant differences among trees height and crown defoliation of pine trees representing 4 different GG was detected. Mean value of competition intensity between trees representing these GGs was also statistically significant. Trees which demonstrated the biggest dendrometric parameters, healthiest crown condition and highest increment rate represented separate GG, while trees with adverse characteristics another one. Key meteorological parameters which resulted in pine tree ring formation were as follows: precipitation amount in October, November, February, June and July, and mean temperature in January, June and August. Significance of their integrated effect on pine growth was in relation to their dendrometry, crown condition and increment. Negative effect of ammonium deposition and positive effect of nitrate deposition on tree ring formation of trees representing GG could be presented as key findings that tree genome has significant effect on sensitivity of pine trees to air pollution acidifying compounds and their deposition. Notwithstanding this effect of tree genotype in lower contents resulted in formation of tree dendrometric parameters comparing with the effect of tree competition intensity.

\section{Acknowledgement}

The study is based on the newest results obtained conducting national project supported by Lithuanian Council of Research "FOREstRESS" (SIT- 3/2015).

\section{REFERENCES}

1. Augustaitis, A. 2011. Impact of Meteorological Parameters on Responses of Pine Crown Condition to Acid Deposition at Aukštaitija National Park. Baltic Forestry, Vol. 17, pp. 205-214.

2. Augustaitis, A., Augustaitienè, I., Činga, G., Mažeika, J., Deltuvas, R., Juknys, R., Vitas, A. 2007a. Did the Ambient Ozone Affect Stem Increment of Scots Pines (Pinus sylvestris L.) on Territories under Regional Pollution Load? Step III of Lithuanian Studies. The Scientific World Journal, Vol.7, pp. 58-66. https://doi.org/10.1100/tsw.2007.55 
3. Augustaitis, A., Augustaitienè, I., Deltuvas, R. 2007b. Scots Pine (Pinus sylvestris L.) Crown Defoliation in Relation to the Acid Deposition and Meteorology in Lithuania. Water Air and Soil Pollution, Vol. 182, pp. 335-348. https://doi.org/10.1007/s11270$\underline{007-9345-9}$

4. Augustaitis, A., Augustaitienė, I., Kliučius, A., Pivoras, G., Šopauskienė, D., Girgždienė, R. 2010a. The seasonal variability of air pollution effects on pine conditions under changing climates. European Journal of Forest Research, Vol. 129, pp. 431-441. https://doi.org/10.1007/s10342-009-0319-X

5. Augustaitis, A., Šopauskienè, D., Baužienè, I., 2010b. Direct and Indirect Effects of Regional Air Pollution on Tree Crown Defoliation. Baltic Forestry, Vol. 16, pp. 23-34.

6. Augustaitis, A., Augustaitienė, I., Mozgeris, G., Juknys, R., Vitas, A., Jasinevičienė, D. 2015. Growth patterns of Scots pine (Pinus sylvestris L.) under the current regional pollution load in Lithuania. iForest, Vol. 8, pp. 509-516.

7. Augustaitis, A., Augustaitienè, I., Baugarten, M., Bičenkienė, S., Girgždienè, R., Kulbokas, G., Linkevičius, E., Marozas, V., Mikalajūnas, M., Mordas, G., Mozgeris, G., Petrauskas, E., Pivoras, A., Šidlauskas, G., Ulevičius, V., Vitas, A., Matyssek, R. 2018. Tree-ring formation as an indicator of forest capacity to adapt to the main threats of environmental changes in Lithuania. Science of the Total Environment, Vol. 615, pp. 1247-1261. https://doi.org/10.1016/j.scitotenv.2017.09.169

8. Augustaitis, A., Bytnerowicz, A. 2008. Contribution of ambient ozone to Scots pine defoliation and reduced growth in the Central European forests: A Lithuanian case study. Environmental Pollution, Vol. 155, pp. $436-445$. https://doi.org/10.1016/j.envpol.2008.01.042

9. Baillie,,L., Pilcher, J.R. 1973. A simple cross-dating program for tree-ring research. Tree-Ring Bulletin, Vol.33, pp. 7-14.

10. Biging, GS., Dobbertin, M. 1992. A comparison of distance-dependent competition measures for height and basal area growth of individual conifer trees. Forest Science, Vol. 38, pp. 695-720.

11. Danusevicius, D., Kerpauskaite, V., Kavaliauskas, D., Fussi, B., Konnert, M., Baliuckas, V. 2016. The effect of tending and commercial thinning on the genetic diversity of Scots pine stands. European Journal of Forest Research, Vol. 135, pp. $1159-1174$. https://doi.org/10.1007/s10342-016-1002-7

12. Fabian P., Menzel A. 1999 Growing season extended in Europe. Nature, Vol. 397, pp. 659. https://doi.org/10.1038/17709

13. Hegyi, F. 1974. A simulation model for managing jack-pine stands. In: FRIES, J., Hrsg., Growth models for tree and stand simulation. Res. Notes. Vol. 30, Royal College of Forestry, Stockholm, Sweden, pp. 74-90.

14. Holmberg, M., Vuorenmaaa, J., Poschb, M., Forsius, M., Lundin, L., Kleemola, S., Augustaitis, A., Beudert, B.; Wit, H.A. de; Dirnböck, T., Evansh, D., Frey, J., Grandin, U., Indriksone, I., Krám, P., Pompei, E., Schulte-Bisping, H., Srybny, A., Váňa, M. 2013. Relationship between critical load exceedances and empirical impact indicators at Integrated Monitoring sites across Europe. Ecological Indicators. Vol. 24, pp. 256-265. https://doi.org/10.1016/j.ecolind.2012.06.013

15. Holmes E., Lewis A., Banks E., Veit R. 1994. Partial Differential Equations in Ecology: Spatial Interactions and Population Dynamics. Ecology, Vol. 75, pp. 17-29. https://doi.org/10.2307/1939378

16. Juknys, R., Vensloviene, J., Stravinskiene, V., Augustaitis, A., Bartkevicius, E. 2003. Scots pine (Pinus sylvestris L.) growth and condition in a polluted environment: From decline to recovery. Environmental Pollution, Vol. 125, pp. $205-212$. https://doi.org/10.1016/S0269-7491(03)00070-8

17. Juknys, R., Augustaitis, A., Venclovienė, J., Kliučius, A., Adomas, V., Bartkevičius, E., Jurkonis, N. 2014. Dynamic response of tree growth to changing environmental pollution. European Journal or Forest research, Vol. 133, pp. 713-724. https://doi.org/10.1007/s10342-013-0712-3

18. Kairiukstis, L., Grigaliunas, J., Skuodiene, L., Stravinskiene, V. 1987. Physiological and dendrochronological indications of forest decline and their application for monitoring, in: Kairiukstis, L., Nilsson, S., Straszak, A. (eds), Forest decline and reproduction: regional and global consequences. IIASA, Luxenburg, pp. 151-169.

19. Linkevičius, E., Kuliešis, A., Röhle, H., Schröder, J. 2011. The new forest growth modelling approach in Lithuania: single tree level models. Fifth International scientific conference „, Rural development in global changes 2011 “, Vol. 5, pp. 74-81.

20. Linkevičius, E., Kuliešis, A., Röhle, H., Schröder, J., Aleinikovas, M. 2014. The impact of competition for growing space on diameter, basal area and height growth of pine trees. Baltic Forestry, Vol. 20(2), pp. 300-313.

21. Lithuanian forest inventory. 2017. Lietuvos miškų valstybinè apskaita. (2017 January 01) Retrieved from http://www.amvmt.lt/Images/veikla/stat/Apskaita/2017.01.01/IVADAS.doc [In Lithuanian]

22. Mäkinen, H., Nojd, P., Mielikinen K., 2001. Climatic signal in annual growth variation in damaged and healthy stands of Norway spruce [Picea abies (L.) Karst.] in southern Finland. Trees, Vol. 15, pp. 177-185. https://doi.org/10.1007/s004680100089

23. Ozolincius, R., Stakenas, V. 2001. Influence of Sulphur Deposition and Drought Stress on Forest Condition in Lithuania. Baltic Forestry 7, pp. 18-23.

24. Ozolincius, R., Stakenas, V., Serafinaviciute, B. 2005. Meteorological factors and air pollution in Lithuanian forests: Possible effects on tree condition. Environmental Pollution, Vol. 137, pp. 587-595. https://doi.org/10.1016/j.envpol.2005.01.044

25. Paoletti, E., Bytnerowicz, A., Andersen, H.-E., Augustaitis, A., Ferretti, M., Grulke, N., Günthardt-Goergb, M.S., Innes, J., Johnson, D., Karnosky, D., Luangjame, J., Matyssek, R., McNulty, S., Muller - Starck, G., Musselman, R., Percy, K. 2007. Impacts of Air Pollution and Climate Change on Forest Ecosystems - Emerging Research Needs. The Scientific World Journal, Vol. 7 , pp. 1-8. https://doi.org/10.1100/tsw.2007.52

26. Kim, D., Yu, T., Shin, S., Yi, H., Yoon, M., Kim, J., Sung, G., Jung, G. 2012. A Study on the Plants for Phenology of the Mt. Palgongsan Pretzsch, H. 2009. Forest Dynamics, Growth, and Yield. In: Forest Dynamics, Growth and Yield. Springer, Berlin, Heidelberg.

27. Pretzsch, H. 1995. Zum Einfluß des Baumverteilungsmusters auf den Bestandeszuwachs. Allgemeine Forstund Jagdzeitung, Vol. 166, pp. 190-201. 
28. Schroder, J. 2004. Zur Modellierung von Wachstum und Konkurrenz in Kiefern/Buchen-Waldumbaubeständen Nordwestsachsens, Ulmer, Stuttgart, p. 271. [In Lithuanian]

29. Sicard, P., Augustaitis, A., Belyazid, S., Calfapietra, C., de Marco, A., Fenn, M., Bytnerowicz, A., Grulke, N., He, S., Matyssek, R., Serengil, Y., Wieser, G., Paoletti, E. 2016. Global topics and novel approaches in the study of air pollution, climate change and forest ecosystems. Environmental Pollution, Vol. 213, pp. 977-987. https://doi.org/10.1016/j.envpol.2016.01.075

30. Taeger, S., Zang, C., Liesebach, M., Schneck, V., Menzel, A., 2013. Impact of climate and drought events on the growth of Scots pine (Pinus sylvestris L.) provenances. Forest Ecology and Management, Vol. 307, pp. 30-42. https://doi.org/10.1016/j.foreco.2013.06.053

31. Tardif, J, Flannigan, M, Bergeron, Y. 2001. An analysis of the daily radial activity of 7 boreal tree species, North-western Québec. Environmental Monitoring and Assessment, Vol. 67, pp. 141-160. https://doi.org/10.1023/A:1006430422061

32. Vuorenmaa, J., Augustaitis, A., Beudert, B., Klarke, N., de Wit, HA., Dirnböck, T., Frey, J., Forsius, M., Indriksone, I., Kleemola, S., Kobler, J., Krám, P., Lindroos, AJ., Lundan, L., Ruoho-Airolal, T., Ukonmaanaho, L., Vá na, M. 2017. Long-term sulphate and inorganic nitrogen mass balance budgets inEuropean ICP Integrated Monitoring catchments (1990-2012). Ecological Indicators, Vol. 76, pp. 15-29. https://doi.org/10.1016/j.ecolind.2016.12.040

33. White E., Leslie E., Calvi R., Marzluff F., Duronio, J. 2007. Developmental and cell cycle regulation of the Drosophila histone locus body. Molecular Biology of the Cell, Vol. 18, pp. 2491-2502. https://doi.org/10.1091/mbc.E06-11-1033

34. Whitham, G., Bailey, K., Schweitzer, A., Shuster, M., Bangert. K., leroy, J., Lonsdorf, E., Allan, J., Difazio, P., Potts, M., Fischer, G., Gehring, A., Lindroth, L., Marks, J., Har, C., Wooley, C. and Wimp, M. 2006, Community and ecosystem genetics: a framework for integrating from genes to ecosystems. Nature Reviews Genetics, Vol. 7, pp. 510-523. https://doi.org/10.1038/nrg1877

35. Wykoff, R., Crookston, L., Stage, R., 1982. User's Guide to the Stand Prognosis Model. USDA For. Serv. Gen. Tech. Rep. INT133

36. Zang, C., Pretzsch, H., Rothe, A., 2012. Size-dependent responses to summer drought in Scots pine, Norway spruce and common oak. Trees, Vol. 26, Iss. 2, pp 557-569. https://doi.org/10.1007/s00468-011-0617-Z 